\title{
APPLICATION OF MFRS 141: INSIGHTS FROM FINANCIAL STATEMENTS OF COMPANIES IN MALAYSIA
}

\author{
SITI NURIZZATI JAMIL, SHAHNAZ ISMAIL* AND AKMALIA MOHAMAD ARIF
}

School of Maritime Business and Management, Universiti Malaysia Terengganu, 21030 Kuala Nerus, Terengganu, Malaysia

\section{*Corresponding author: shahnaz@umt.edu.my}

\begin{abstract}
This study examined biological asset information that has been reported by companies in Malaysia and the methods of valuation used in reporting the biological assets. It aimed to provide useful information to the regulators about the application of MFRS 141, the accounting standards for agriculture, in corporate reporting. This study employed the data derived from the 2016 annual reports of plantation companies listed on Bursa Malaysia. Descriptive analysis was used to examine the biological asset information that has been reported and the characteristics of the companies such as age, size, and leverage. The results of this study showed that most of the plantation companies believed that fair value and historical cost could be the best way to measure their biological assets. The findings of this study provide input towards identifying the gap in corporate reporting practices and the challenges faced by companies in the application of MFRS 141. The findings are expected to contribute to the regulatory improvement towards increasing the full adoption of MFRS 141 by companies in Malaysia.
\end{abstract}

Keywords: biological assets, environmental accounting, green reporting, MFRS 141

\section{Introduction}

Malaysia is a newly industrialized country and aims to become a developed nation by 2020. Its main economy is contributed by the service sector, followed by the manufacturing, mining and agricultural sectors. Despite being a small contributor, the agricultural sector is still important as it supplies food and creates employments for rural people (Rozhan, 2015). Furthermore, in stepping to the new era of modernization, the development of agricultural sector has continued to enhance the economic growth of Malaysia. In 2016, there were 39 public listed companies on the main market of Bursa Malaysia that were involved in plantation. TDM Bhd, Sime Darby Bhd and Felda Bhd were some examples.

In Malaysia, there are three types of agricultural activities, namely estates, land development schemes and independent smallholdings. According to Colin (2012), the estates are what many people term 'plantations', with individual units being large and commonly covering 2,000-10,000 hectares. The units are often grouped in big estate companies. For example, Sime Darby controls 500,000 hectares, 300,000 of which are in Malaysia. The land development schemes are also extensive, with those managed by the Federal Land Development Authority (Felda) being the most significant and frequently managed like estates. In contrast, independent smallholdings are limited to 1-2 hectares, and are managed by family households which often only work part-time.

The plantations are divided into many areas such as palm oil, rubber, cocoa, fruits and many more. Besides plantation, agriculture also includes businesses such as breeders to provide livestock products such as chickens, goats, and cows. Since Malaysia has been the second largest producer in palm oil and palm oil products (DSM, 2015), it has an important role to play in fulfilling the growing global need for oils and fats sustainably. According to the Department of Statistics, Malaysia (DSM), the agricultural sector contributed RM1,062.8 billion which was $8.9 \%$ of the Gross Domestic Product in 2015. The highest agriculture activity was oil palm $(46.9 \%)$, followed by rubber $(7.2 \%)$, livestock product $(10.7 \%)$ and others $(17.7 \%)$.

In general, plantation companies in Malaysia should report their biological assets in the financial statements in accordance to Malaysian Accounting Standards Board (MASB), the Companies Act 1965, the Securities Commission's guidelines and the Bursa Malaysia's listing requirements (Tan, 2010). The presentation or disclosure of the biological assets basically will appear in the Statement of Financial Position as required by the standards. The introduction of International Financial Reporting Standards (IFRS) framework by International Accounting Standards Board (IASB) has led certain countries, including Malaysia, to adopt the same standards in an attempt to increase harmonisation in an accounting presentation and disclosure. Under this framework, biological assets are categorised into consumable biological assets which are to be accounted within the scope of IAS 41 Agriculture, and bearer biological assets which are to be accounted under the scope of IAS 16 Property Plant and Equipment (Muhammad and Ghani, 2013). 
In November 2011, MASB issued MFRS 141 Agriculture. The Standard is applicable for annual periods beginning on or after 1 January 2012. MFRS 141 is equivalent to IAS 41 Agriculture as adopted and amended by the International Accounting Standards Board (IASB). It means that all the valuation methods and disclosures would be the same. Issues arise when most of the companies cannot comply with the standards as the fair values are hard to determine and some of the companies are not yet ready. Due to this, MASB (2014) stated that MFRS 141 fair value model is based on the principle that biological transformation is best reflected by fair value measurement. However, once bearer plants mature, their biological transformation is no longer significant and they are held by an entity solely to grow produce. Accordingly, bearer plants should be accounted for under MFRS 116 instead of MFRS 141 for annual period beginning or after 1 January 2016.

According to Thurrun Bhakir (2010), 43 oil palm plantation entities listed on the Bursa Malaysia accounted their biological assets as required by the standards. However, only few companies adopted fair value method. He also found that the companies were having difficulty in identifying the attributes of biological asset, the cost of fair value valuation and relevant information in order to implement IAS 41, the standard for biological assets.

The challenges facing the publicly listed companies in the application of the fair value accounting of biological assets and agricultural activities as well as the reporting thereof should be investigated to determine the main reasons for not implementing the requirements set in MFRS 141 for biological assets and agriculture: bearer plants (amendments to MFRS 116 and MFRS 141) between 2014 and 2016. Therefore, this study examined the application and implementation of early adoption of MFRS 141 in the publicly listed companies in Malaysia.

\section{Literature Review \\ Fair Value Accounting For Biological Assets}

It is generally accepted that fair value accounting provides more relevant information for user decisionmaking and improves transparency (Barth, 1996) because the valuation itself is very important and has a purpose to represent certain assets' attributes by using the appropriate assessment base. Nevertheless, Hague and Willis (1999) stated that the use of fair value brings information about missed opportunities, intervening in the economic evaluation of the companies. The issues that have been raised are fair value of biological assets cannot be easily determined due to absence of market and difficulty in identifying the attributes of bearer biological assets, cost to be incurred in the determination of fair value outweighs the benefit and there is a lack of relevant information and knowledge related to the measurement of biological assets and bearer plants (Thurrun Bhakir, 2010)
In the absence of markets, management needs to rely on estimates and judgments to determine the fair value of biological assets (Scott, Wingard and Biljon, 2016). However, according to IAS 41, they have provided ways in identifying fair value of biological assets. One way is to determine the existence of an active market for the biological assets. If there is an active market for the biological assets, then the fair value should be based on the quoted market price. Other than that, biological assets also can be traded in more than one market. A research in Brazil conducted by Brito et al. (2014) indicated that the prices practiced in an active market can be more uncommitted than those practiced in a negotiation only between two parties. Moreover, in an efficient and competitive market, the large number of participants does not allow for individuals to have effects on prices.

The use of fair value in measuring the biological assets and agricultural produce has led to many arguments, such as many biological assets are traded in active markets. Thus, active markets provide relevant and reliable information. Whereas, long production cycles mean that the change in asset value is more relevant than a period-end measure of costs incurred, valuation based on costs is arbitrary when there are joint products and joint costs, different sources of animals and plants (e.g. home-grown or purchased) should not be measured differently which will occur if the historic cost valuation model is used rather than the fair value model.

Besides, the IASB proved that the fair value measurement provides relevant information and the information is more comparable and understandable. But, IASB also mentioned the exception that fair value may not be able to be measured reliably where market prices are not available and alternative estimates of fair value are determined to be clearly unreliable for certain cases. However, this exception can only be applied on initial recognition of the biological asset.

\section{Related Disclosures}

The results of accounting recognition and measurement on biological assets involved in agricultural activities need to be passed to the users by way of information disclosure. Complete, fair, standardized information disclosure is a vital link in the agricultural accounting (Qing-wan, Peng and Gang, 2013). A previous study from Qing-wan et.al (2013) indicated that there were reasons to disclose the biological assets for listed companies in China such as highest cost of information disclosure and the need to maintain the stock price and inadequate market supervision. Highest cost of information means that in order for listed companies to complete the disclosure of information and to reach the standards of information disclosure, it takes a lot of manpower, material and financial resources to classify the relevant business of financial information and information production costs cannot be compensated 
from the provided accounting information. Therefore, companies generally do not provide further disclosure beyond the rules. Next, the need to maintain the stock price is to get a full disclosure of biological asset information that will help to improve the value of the enterprise. However, because of the agency relationship of listed companies, the entire disclosure of certain information may disclose the company's trade secrets, or extensive disclosure of some losses, asset disposal, and mortgage might have a greater negative impact on the company and a direct impact on investors' expectations, causing the stock price to fall, affecting the performance of the company. Consequently listed companies trry not to disclose such information as far as possible. Inadequate market supervision given that the supervision of China's securities are relatively weak, lacking the necessary enforcement means those who break the rules often get a comparatively light punishment. In addition, the certified public accountants' audit regulatory functions also need to be improved. Besides the audit business, CPAs offer their specific clients a wide range of management consulting services, which may also lead to audit failure and non - standard disclosure. Elad and Herbohn (2011) indicated that the checklist of disclosures prescribed by IAS 41 was used as a basis for assessing the extent of compliance for the companies selected.

PricewaterhouseCoopers (PwC) (2011) has elaborated two international studies concerning the impact of adopting the IAS 41 in the timber sector. The main goal was to provide what might be considered establishing best practices in fair valuing of this sector and the related disclosures. Additionally, in both studies, PWC has identified the major pronouncements described in the notes of the financial statements, highlighting some of the main constraints, comparisons and dissimilarities. In general, firms have different levels of transparency regarding biological asset disclosure and usually they do not discuss fair valuation assumptions, so there is an opportunity for further improvement. PWC (2011) has recommended several practices in this field such as to present key valuation assumptions, for example, the forest and harvest plans and the complexity of the structure of the asset. Next is to discuss expected future prices and costs to better understand the valuation adopted and to provide a sensitivity analysis related to each weight assumption used in the valuation that has an effect on the value in case of a change, for example, discount rate, prices, costs and growth.

\section{Valuation Techniques for Biological Assets}

There are many ways to value the biological assets such as historical cost, fair value, net present value and many more (Elad and Herbohn, 2011). Specifically, it depends on the companies what techniques to be used in order for them to value the biological assets. According to Elad and Harbohn (2011), there are two further inferences can be drawn from the collected data. First, the variety of valuation approaches used by agricultural entities indicates that IAS 41 has failed to enhance the comparability of farm accounting practices within each of the three countries. This finding can be explained in terms of the range of proxies for fair value available to companies under the standard, such as the net present value, independent valuer's recommendation, sector benchmark price, recent market price, or market price for similar assets. Hence, entities that simply state that their biological assets are measured at fair value, without providing further details on how the latter was derived, may conceal useful information that is not taken into account. Second, the chi-square test was used to test for differences in the asset valuation methods of UK and Australian agricultural entities. The low frequencies for market price for similar asset, lower cost and net realisable value, and recent market price were treated as 'other methods'. Surprisingly, the results revealed that there was no significant difference $\left(\mathrm{X}_{2}=2.688\right.$, $\mathrm{p}$-value $=0.611$ ) between the methods used in valuing biological assets in Australia and the UK. A three country comparison was not carried out because the low frequencies for France would have invalidated the chisquare test. So, this study concluded that the higher level of convergence on only two approaches to the valuation of biological assets in France, unlike Australia and the UK, warranted further analysis.

\section{Methodology}

This was a cross sectional analysis which employed Bursa Malaysia public listed plantation companies. Plantation companies were selected under the main market according to Bursa Malaysia classification. There were 40 plantation companies in total that were selected for the analysis. The main source of data was the companies' annual reports for the year 2016. The main reason for using the annual reports was that listed companies are governed by regulations and laws that require high compliance, and, therefore, the annual reports are assumed to have high quality in reporting which meet the standards required in financial reporting.

Descriptive analysis was used to identify and examine the mandatory disclosure of biological assets by the companies. Besides that, content analysis method was also used to examine the disclosure of biological asset items in the financial statements of the companies. Dummy value of one (1) was used for disclosure of item and zero (0) otherwise.

\section{Results and Discussion Descriptive Analysis}

There were 40 plantation companies listed on Bursa Malaysia, divided into two types of biological assets under MFRS 141: plantation (including oil palms, rubber, forest, etc) and combination of livestock and plantation. Specifically, 34 companies were categorised under plantation and 6 companies were categorised under 
combination of livestock and plantation. The descriptive results of the study are shown in Table 4.1.

Table 4.1: Results of the Descriptive Analysis

\begin{tabular}{ll}
\hline Age of Company & 15 Years - 122 Years \\
Year Established & $1894-2001$ \\
Year Listed & $1968-2012$
\end{tabular}

Referring to Table 4.1, the listed companies have been established since the year 1894 and listed since 1968. These companies have been operating for as long as between 15 and 122 years. Most of these companies are palm-oil-based plantation companies and have been the key contributors to the Malaysian economy for many decades such as Sime Darby, IOI Corporation, Kuala
Lumpur Kepong Berhad, Genting Plantations, Felda Global Ventures Holdings and United Plantations.

As for the disclosures, there are 12 mandatory disclosures required by MFRS 141 for biological assets as listed in Table 4.2. For every item disclosed, a score of 1 point was given.

Table 4.2: Item disclosed by listed companies

Mandatory disclosures

Number of companies Percentage (\%)

$(\mathrm{n}=40)$

1. Description of biological assets

2. Description of enterprise's activities

3. Gain or loss arising from changes in fair value

4. Physical quantity of biological assets

5. Assumptions in determining fair value

6. Physical quantity of output

7. Reconciliation of changes in the carrying amount of biological assets, showing separately the gain or loss arising from changes in fair value

8. Financial risk management strategies

9. Fair value of produce harvested

10. Reconciliation of changes in the carrying amount of biological assets, showing separately increases due to purchase

11. Reconciliation of changes in the carrying amount of biological assets, showing separately decreases due to sales

12. Reconciliation of changes in the carrying amount of biological assets, showing separately decreases due to harvest

$\begin{array}{cc}25 & 62.5 \% \\ 36 & 90 \% \\ 11 & 27.5 \% \\ \text { Nil } & \text { Nil } \\ 27 & 67.5 \% \\ \text { Nil } & \text { Nil } \\ 4 & 10 \% \\ & \\ 5 & 12.5 \% \\ 2 & 5 \% \\ \text { Nil } & \text { Nil } \\ & \\ \text { Nil } & \text { Nil } \\ & \\ \text { Nil } & \text { Nil }\end{array}$

Based on the results shown in Table 4.2, the highest compliance was for the item "description of enterprise's activities" with a percentage of $90 \% \quad(n=36)$. It is common for the company to describe their enterprise's activities in the notes to financial statement to provide such information to potential investors and shareholders. However, there were $4(10 \%)$ companies that did not describe their enterprise's activities.

The lowest compliance was the disclosure for "the fair value of produce harvested" where only two companies $(5 \%)$ disclosed. This result might be due to the fact that the adoption of MFRS141 is not yet mandatory. These two companies showed advanced adoption of this disclosure. The other 39 companies were still under Transitioning Entities that would be made mandatory for the disclosure for annual periods beginning on or after $1^{\text {st }}$ January 2018.

Table 4.2 also shows that there were several mandatory disclosures that were not complied with by any plantation companies listed in Bursa Malaysia and these results were shown as 'nil'. These disclosures were physical quantity of biological assets, physical quantity of output, reconciliation of changes in the carrying amount of biological assets (showing separately 
increases due to purchase), reconciliation of changes in the carrying amount of biological assets (showing separately decreases due to sales) and reconciliation of changes in the carrying amount of biological assets (showing separately decreases due to harvest).
Table 4.3 shows the total disclosure score for every plantation company listed on Bursa Malaysia under main market.

Table 4.3: Total disclosure score by companies

\begin{tabular}{|c|c|c|}
\hline & Company & $\begin{array}{l}\text { Disclosure } \\
\text { score }\end{array}$ \\
\hline 1. & NEGRI SEMBILAN OIL PALMS BERHAD & 4 \\
\hline 2. & INCH KENNETH KAJANG RUBBER PUBLIC LTD CO & 3 \\
\hline 3. & SARAWAK OIL PALMS BERHAD & 2 \\
\hline 4. & ASTRAL ASIA BERHAD & 3 \\
\hline 5. & SIN HENG CHAN (MALAYA) BERHAD & 1 \\
\hline 6. & HARN LEN CORPORATION BHD & 3 \\
\hline 7. & HAP SENG PLANTATIONS HOLDINGS BERHAD & 2 \\
\hline 8. & RIMBUNAN SAWIT BERHAD & 4 \\
\hline 9. & TDM BERHAD & 4 \\
\hline 10. & TSH RESOURCES BERHAD & 4 \\
\hline 11. & GOPENG BERHAD & 2 \\
\hline 12. & KRETAM HOLDINGS BERHAD & 3 \\
\hline 13. & INNOPRISE PLANTATIONS BERHAD & 2 \\
\hline 14. & RIVERVIEW RUBBER ESTATES BERHAD & 5 \\
\hline 15. & FELDA GLOBAL VENTURES HOLDINGS BERHAD & 3 \\
\hline 16. & NPC RESOURCES BERHAD & 3 \\
\hline 17. & FAR EAST HOLDINGS BERHAD & 1 \\
\hline 18. & BLD PLANTATION BHD. & 2 \\
\hline 19. & SARAWAK PLANTATION BERHAD & 1 \\
\hline 20. & CEPATWAWASAN GROUP BERHAD & 3 \\
\hline 21. & MHC PLANTATIONS BHD & 4 \\
\hline 22. & TH PLANTATIONS BERHAD & 2 \\
\hline 23. & GENTING PLANTATIONS BERHAD & 2 \\
\hline 24. & BOUSTEAD PLANTATIONS BERHAD & 4 \\
\hline 25. & UNITED PLANTATIONS BERHAD & 2 \\
\hline 26. & BATU KAWAN BERHAD & 4 \\
\hline 27. & KUALA LUMPUR KEPONG BERHAD & 4 \\
\hline 28. & CHIN TECK PLANTATIONS BERHAD & 3 \\
\hline 29. & KWANTAS CORPORATION BERHAD & 3 \\
\hline 30. & GOLDEN LAND BERHAD & 5 \\
\hline 31. & PINEHILL PACIFIC BERHAD & 3 \\
\hline 32. & KLUANG RUBBER COMPANY (MALAYA)BERHAD & 3 \\
\hline 33. & SUNGEI BAGAN RUBBER COMPANY (MALAYA) BERHAD & 3 \\
\hline 34. & MALPAC HOLDINGS BERHAD & 2 \\
\hline 35. & DUTALAND BERHAD & 4 \\
\hline 36. & IOI CORPORATION BERHAD & 6 \\
\hline 37. & PLS PLANTATIONS BERHAD & 3 \\
\hline 38. & IJM PLANTATIONS BERHAD & 0 \\
\hline 39. & KIM LOONG RESOURCES BERHAD & 2 \\
\hline 40. & SIME DARBY BERHAD & 3 \\
\hline
\end{tabular}

Referring to Table 4.3 above, the highest disclosure score for a company was 6 out of 12 items. The lowest disclosure score was shown by IJM Plantation Bhd with a score of nil. The highest compliance was IOI Corporation Bhd with a score of 6 . The second highest score was 5 items disclosed by Riverview Rubber Estate Bhd. Most of the companies $(n=40,35 \%)$ disclosed at least 3 items and nine companies disclosed 4 items (22.5\%). The summary of the compliance score by companies is as tabulated in Table 4.4. 
Table 4.4 : The frequency of compliance by public listed plantation companies on Bursa Malaysia

\begin{tabular}{cc}
\hline Compliance score & Total number of companies \\
\hline 0 & 1 \\
1 & 3 \\
2 & 10 \\
3 & 14 \\
4 & 9 \\
5 & 2 \\
6 & 1 \\
\hline Total & 40 \\
\hline
\end{tabular}

According to Kclim (2009), plantation development expenditure comprises assets held for plantation development activities. These assets include land and buildings used for the purpose of plantation development, infrastructure costs such as roads and bridges attached on the plantation estate and cost of planting and development of crops. This is stated at cost less accumulated depreciation and impairment losses, if any. Freehold land is stated at cost and is not depreciated. Table 4.5 below shows the valuation basis used in valuing biological assets by 40 plantation companies on Bursa Malaysia.

Table 4.4 :Valuation basis to value biological assets

\begin{tabular}{lc}
\hline Valuation basis & Number of companies \\
\hline 1. Net Present Value & Nil \\
2. Historic Cost (HC) & 13 \\
3. Fair Value (FV) & 14 \\
4. Independent Valuation & Nil \\
5. Market Price & Nil \\
6. Not Stated & 10 \\
7. Combination of FV and HC & 3 \\
\hline Total & 40 \\
\hline
\end{tabular}

As per Table 4.5, the results showed that most of the companies were using fair value method to value their biological assets. According to IAS 41, fair value method is the most reliable method for companies to value their biological assets as it provides more relevant information for users' decision-making and improves transparency in reporting. There are two valuation techniques used in measuring fair value, namely discounted cash flows and market comparison technique. Table 4.6 describes both of these techniques as used in the annual report of Negeri Sembilan Oil Palms Bhd.

Table 4.6: Description of the type of valuation techniques

\begin{tabular}{ll}
\hline Valuation techniques & Descriptions \\
\hline Discounted cash flows & $\begin{array}{l}\text { The valuation model considers the present value of the net cash } \\
\text { flows expected to be generated by the plantation. The cash flow } \\
\text { projections include specific estimates for 25 years. The expected } \\
\text { net cash flows are discounted using a risk-adjusted discounted rate. }\end{array}$ \\
\hline Market comparison techniques & $\begin{array}{l}\text { Entails analysis on recent transactions and asking prices of similar } \\
\text { properties in and around the locality for comparison to derive } \\
\text { unimproved land values for all estates and market value with } \\
\text { adjustment made for differences in location, terrain, size, shape of } \\
\text { land, tenure, title restrictions if any, cultivation and other relevant } \\
\text { characteristics to arrive at the market value. }\end{array}$ \\
\hline (Source $:$ Annual Report of Negeri Sembilan Oil Palms Berhad, 2016, page 82)
\end{tabular}




\section{Content Analysis}

The first step in conducting the content analysis was the diagnostic checking followed by an explanation on the disclosure content. Table 4.7 below shows the list of the 12 mandatory items for disclosure of MFRS 141, Biological Assets.

Table 4.7: Mandatory disclosures under IAS 41 and MFRS 141

\begin{tabular}{ll}
\hline & Mandatory disclosures \\
\hline 1. Description of biological asset \\
2. Description of enterprise's activities \\
3. Gain or loss arising from changes in fair value \\
4. Physical quantity of biological assets \\
5. Assumptions in determining fair value \\
6. Physical quantity of output \\
7. Reconciliation of changes in the carrying amount of biological assets, showing separately the gain \\
8. Financial risk management strategies \\
9. Fair value of produce harvested \\
10. Reconciliation of changes in the carrying amount of biological assets, showing separately \\
11. Reconciliation of changes in the carrying amount of biological assets, showing separately \\
12. Reconciliation of changes in the carrying amount of biological assets, showing separately \\
\hline
\end{tabular}

Referring to Table 4.7, the first mandatory disclosure item that is usually required by the standards is the description of biological asset. Basically, the company will describe their biological assets on livestock and growing crops, plantation development expenditure and replanting expenditure. The companies will explain the biological assets in their companies, the measurement and also the estimated productive years. Below are examples extracted from the annual reports of a selected company.

\section{Plantation development expenditure}

New planting expenditure incurred on land clearing and upkeep of trees to maturity is capitalised as plantation development expenditure under biological assets. Plantation development expenditure is not amortised except for those short land leases held in Indonesia where the plantation development expenditure is amortised using the straight line method over the estimated productive years of 20 years.

\section{Growing crops and livestock}

Growing crops are measured at fair value which is based on the costs incurred to the end of the reporting period for these crops. As at the end of the reporting period, the yield of the crops and the future economic benefits which will flow from the crops are not able to be reliably measured due to the level of growth.

Livestock is measured at fair value less point-of-sale cost, with any change therein recognised in profit or loss. Fair value is based on the market price of livestock of similar age, breed and genetic make-up. Pointof-sale costs include all costs that would be necessary to sell the livestock.

(Source: Annual Report of Kuala Lumpur Kepong Berhad, 2016, page 10)

The second item is description of enterprise's activity. The first note in the financial statement basically will be the corporate information or general information that usually mentions the principal activities of the group. For example, Kuala Lumpur Kepong Berhad (KLKB) principally engages in the business of producing and processing palm products and natural rubber on its plantations.
Gain or loss arising from the changes in fair values is usually shown in the statement of Profit or Loss and Other Comprehensive Income. According to $\mathrm{PwC}$ (2009), as the change in fair value may be both a positive as well as a negative amount, it is most appropriate to present the change in fair value after revenues and other income, but before expenses. The presentation should 
take into consideration the unique characteristics of the production of the entity. Usually, gain or loss arising from the changes in fair value occurs when there is a price difference between current market price and previous market price. The reason why there are changes in prices for biological assets is because of age factor (livestock) and high demand from customers (plantation).
Basically, all assets and liabilities in the companies that are measured or disclosed in the financial statements using fair value will be categorised within the fair value hierarchy. There are three levels of fair value measurement and its disclosure as shown in Table 4.8.

Table 4.8: Hierarchy of Fair Value Measurement

\begin{tabular}{ll}
\hline Level & Description \\
\hline Level 1 & $\begin{array}{l}\text { Quoted (unadjusted) market prices in active markets for identical assets or liabilities. } \\
\text { Level 2 }\end{array}$ \\
Laluation techniques for which the lowest level input that is significant to the fair value \\
measurement is directly or indirectly observable.
\end{tabular}

Example of disclosure of fair value measurement of biological assets in an annual report is as follows:

\begin{abstract}
The biological assets are measured at their fair values less estimated point-of-sale costs annually. This requires an estimation of the value in use of the biological assets which involves assumptions made by the management on the crude palm oil prices, fresh fruit bunches yield and oil extraction rate over the remaining useful life of the biological assets adjusted based on indirect observable market data.
\end{abstract}

The fair value measurement for biological assets have been categorised as level 3 using significant unobservable inputs. There have been no transfers between Level 1 and Level 2 during the financial year.

(Source: Annual report of Negeri Sembilan Oil Palms Berhad, 2016, page 70 \& 81)

According to PwC (2009), IAS 41 includes an unofficial hierarchy of valuation measures, similar to those found in IAS 36, "Impairment of assets", and IAS 39, "Financial instruments: Recognition and measurement". Specifically, most of the biological assets have relevant market-determined prices or values available because biological assets produced in general are basic commodities that are traded actively. For example, there are usually market prices for calves and goats, because there is an active market for these assets.

Based on IAS 41 para 48 , every company is required to disclose the fair value less costs to sell of agricultural produce harvested in a period. On top of that, this is applied whether the quantity is sold or not. The disclosures should be made in the notes of the financial statements. However, there is no guidance mentioned in the standards regarding the disclosure of the cost of the agricultural produce when it is sold. Thus, the best practice is to present the cost of the produce as cost of goods sold, by separating the production phase from the selling phase. IAS 1 para 32 does not permit offset or showing a net position in the annual report. An example of such disclosure in the annual report of a listed company is as shown below:

\footnotetext{
"The harvested produce (fresh fruit bunches) are sold immediately after being harvested. Therefore, the requirement under IAS 41 to value agricultural produce at market value as inventories does not apply"
}

(Source: Annual Report of Inch Kenneth Berhad, 2016, page 51)

\section{Conclusion}

In this study, 40 listed plantation-based companies on Bursa Malaysia were examined. Under MFRS 141, these plantations companies are required to disclose their accounting for biological assets in the annual report and 12 mandatory disclosures were analysed. Out of 12 items, only 7 items were disclosed in the companies' annual reports in the year 2016. The seven items were description of biological assets, description of enterprise's activities, gain or loss arising from changes in fair value, assumptions in determining fair value, reconciliation of changes in the carrying amount of biological assets showing separately the gain or loss arising from changes in fair value, financial risk management strategies and fair value of produce harvested. The remaining items which were physical quantity of biological assets, physical quantity of output, 
reconciliation of changes in the carrying amount of biological assets showing separately increases due to purchase, reconciliation of changes in the carrying amount of biological assets showing separately decrease due to sales and reconciliation of changes in the carrying amount of biological assets showing separately decrease due to harvest were not reported in the annual reports of the plantation companies in the year 2016. This might be due to the exemption of these companies from adopting the MFRS 141 as they are referred to as "Transitioning Entities". These companies will only apply the MFRS 141 Framework for the period beginning on 1 January 2018 onward. However, most of the companies disclosed the basic mandatory disclosure such as description of biological assets and description of enterprise's activities.

The findings from this study will add knowledge to the literature on the disclosures on accounting standards MFRS 141, Biological Assets. For mandatory disclosure, it showed that the highest score for the Plantation companies was only 6 out of 12 . Disclosing the items that are required by the standards is very important for the companies in order to provide quality annual reports. Thus, the preparers of the annual reports should be aware of any changes in the accounting standards.

This study is not free from limitations. Firstly, this study only used the list of the frequency of mandatory disclosure reported by the companies and it was based on secondary data only. Therefore, the details in terms of the reasons behind not disclosing some of mandatory items mentioned in MFRS 141, Biological Assets, were not able to be explained. Secondly, this study only used the annual reports of the companies on Bursa Malaysia instead of interviewing the management of the companies. Therefore, some of the information given in the annual reports was limited and confidential. On top of that, it was impossible to interview all of the plantation companies on Bursa Malaysia due to their locations.

Due to the problems that existed in the calculation for mandatory disclosure, future research is recommended to use other structure of data such as disclosure index. Besides, future researchers are suggested to employ longer period of data which may be 2 to 3 years or even more to investigate whether there are early adoption of MFRS 141 for biological assets. More information or facts should be gathered to investigate whether the results in another time range are consistent with this study. Moreover, it is also suggested to use both primary and secondary data for the mandatory disclosure on biological assets for plantation sector.

\section{Acknowledgements}

The authors acknowledge the helpful comments of anonymous reviewers and participants of the Undergraduate Seminar of PPPPM. The authors would also like to thank the editors of the Undergraduate
Journal UMT for their helpful assistance throughout the preparation of this manuscript.

\section{References}

Barth, M., Beaver W. H. \& Landsman, W. R. (1996). Value-relevance of banks' fair value disclosures under SFAS No 107. Accounting Review. 71 (4), 513537.

Brito, E. D, Ribeiro, M. D. S, Martins, V. A. \& Lemes, S. (2014). Fari value application to biological assets and agricultureal produce in livestock farming. Custos $e$ Agronegocio, 10(1), 190-211.

Clavano M. J. (2014). Factors that influence the valuation of biological assets and compliance with IAS 41/PAS 41 mandatory disclosures by selected agricultural companies in Davao Region. Melbourne Conference 2014. Melbourne: Australia.

Duriau, V. J., Reger, R. K., \& Pfarrer, M. D. (2007). A content analysis of the content analysis in organization studies: research themes, data sources, and methodology refinement. Organization Research Method, 10, 5-34.

Elad, C., \& Herbohn, K. (2011). Implementing the fair value accounting in the agricultural sector. The Institute of Chartered Accountant of Scotland. Retrieved 7 July 2017 from https://www.icas.com

Gongales, R., \& Lopes, P. (2014). Accounting in Agriculture: Disclosure Practices of Listed Firms. Working paper for School of Economics and Management, University of Porto. ISSN:0870-8541.

Muhammad, K., \& Ghani, E. K (2013). A fair value model for bearer biological assets in promoting corporate governance: a proposal. Journal of Agriculture Studies, 2(1):16-26.

Kclim. (2009). Accounting Crash Course. Retrieved 5 August 2017 from http://www.accountingcrashcourse.com.

Pricewaterhouse Coopers (2009). A practical guide to accounting for agricultural assets. Retrieved 30 July 2017 from https://www.pwc.com

Pricewaterhouse Coopers (2011). Building for the Future Annual Report 2011. Retrieved 20 June 2017 from www.pwc.co.uk/annualreport.

Saunders, M., \& Lewis, P. (2016). Research Method for Business Students $7^{\text {th }}$ Edition. Pearson: England.

Scott, D, Wingard, C., \& Biljon, M V. (2015). Challenges with the financial reporting of biological assets by public entities in South Africa. South African Journal 
of Economics and Management Sciences. 19(1), 139149.

Silva, J. D, Rezende, A. J., \& Braunbeck, G. (2016). Judgement of the relevance of fair value in biological assets: A experimental analysis on the market perception versus the academic perception. Faculty of Economics, Administration and Accounting of Ribeirao Preto. Retrieved 10 July 2017 from https://papers.ssrn.com
Thurrun Bhakir, M. I. (2010). Applying IAS 41 in Malaysia. Accountants Today, 32-39.

Qing-wan, T., Peng, G., \& Gang, F. (2013). Research of information disclosure of biological assets of agricultural listed companies in China. Interdisciplinary Journal of Contemporary Research in Business, 4 (11), 12-24. 